\title{
Prema intelektualnoj historiji hrvatskog modernističkog pokreta na prijelomu 19. i 20. stoljeća: stanje istraživanja i istraživački problemi
}

\begin{abstract}
U radu se razlažu teorijski i metodološki problemi istraživanja fenomena hrvatskog modernističkog pokreta na prijelomu 19. i 20. stoljeća. Na temelju analize navedenih problema također se osvrće na stanje istraženosti teme te postojeće istraživačke pristupe, prvenstveno u okviru historiografije. Cilj je rada analizom istraživačkih problema uputiti na teorijske i metodološke mogućnosti za istraživanje fenomena ove vrste koje nudi konceptualni okvir intelektualne historije.
\end{abstract}

\section{Uvod}

Fenomen hrvatskog modernističkog pokreta na prijelomu 19. i 20. stoljeća do danas nije bio predmetom zasebne historiografske analize. ${ }^{1}$ Ona se njime bavila ili u okviru širih problematika, naročito sinteza, ili je u fokusu imala tek određene njegove aspekte, prije svega političke. Nije stoga čudno što je u primarnom fokusu historiografije, onda kada se ona bavila fenomenom pokreta „mladih“, stajala tzv. „praška grupa“, odnosno u širem smislu pokret napredne omladine, dok su literarne, kulturne, pa čak i društvene dimenzije hrvatskog modernističkog pokreta često ostale zanemarene ili tek ovlaš dotaknute. S druge, pak, strane, književna se

* Rad je nastao u sklopu projekta Hrvatske zaklade za znanost „Tranzicija hrvatskih elita iz Habsburške Monarhije u jugoslavensku državu“ (br. 5974), voditeljice prof. dr. sc. Iskre Iveljić.

1 S obzirom na to da on nije bio formaliziran i homogeno strukturiran pokret, ne postoji niti terminološka konzistentnost prilikom njegova imenovanja kako u literaturi, tako i u izvorima. Najčešće ću se koristiti nazivom modernistički pokret „mladih“ ili hrvatski modernistički pokret. Osim što mi se čini da je naziv „mladi“ najzastupljeniji u tekstovima samih aktera pokreta, odnosno da se u njegovu okviru najviše evocirao imagem mladosti, time želim također pridonijeti jedinstvenom i sveobuhvatnom gledanju na ovaj fenomen. U historiografiji, koja se najviše bavila političkim dimenzijama pokreta, najviše se, naime, ustalio naziv ,napredna omladina“, dok su se povjesničari književnosti i povjesničari umjetnosti svojim kulturno-umjetničkim fokusom uglavnom koristili nazivima „hrvatska moderna“ $\mathrm{i}$,secesija“. U tom smislu naziv koji ovdje upotrebljavam i zastupam, osim što ima svoje utemeljenje u izvorima, pomaže u nadvisivanju disciplinarnih podjela pri istraživanju ovog fenomena, a opet jasno naglašava dvije njegove ključne sastavnice: fin de siècle modernizam i smjenu generacija (,mladi“ vs. „stari“). 
historija uglavnom ograničila na hrvatsku modernu kao literarni fenomen kad je riječ o pokretu, odnosno na modernu kao razdoblje novije hrvatske književnosti kad se govori o širem okviru književno-historijske periodizacije. U njezinu je primarnom fokusu, pak, tzv. „bečka grupa“, a često se zanemarivalo ili stavljalo u drugi plan političke intencije i uloge modernističkog pokreta „mladih“. Rezultat je takvog disciplinarnog odvajanja i sužavanja fokusa činjenica da zapravo ne postoji jedan sveobuhvatan pregled tako relevantnog fenomena kao što je fin de siècle modernistički pokret „mladih“.

$\mathrm{U}$ ovome bih radu htio ponuditi pregled onih istraživačkih problema koje smatram ključnima za razumijevanje problematike hrvatskog modernističkog pokreta, prije svega iz intelektualno-historijske perspektive. On ne pretendira na iscrpnost u sadržajnom smislu. Njegov je fokus, naprotiv, na identificiranju temeljnih teorijskih i metodoloških problema kojima se posredno dotičem i sadržaja razmatranog predmeta. Također, ne nudim opsežan $\mathrm{i}$ iscrpan pregled literature o pokretu „mladih“, iako on ne bi bio odviše dug. ${ }^{2}$ Umjesto toga, ispitivanje stanja istraživanja pokreta „mladih“ inkorporirao sam u pregled istraživačkih problema na način da se na najbitnijim mjestima referiram na reprezentativna djela iz određenog polja. Moja je nada da će ovaj kratak pregled uspjeti ustanoviti tematsko značenje hrvatskog modernističkog pokreta te da će, najviše od svega, uputiti na mogućnosti i važnost intelektualno-historijskih istraživanja, posebice u obliku koji se ovdje zagovara i predlaže.

\section{Problem definicije}

Problem definicije modernističkog pokreta nije samo problem preciznosti određenja. Javlja se već na razini razumijevanja same naravi predmeta. Temeljno pitanje jest sljedeće: u kojem smislu govorimo o pokretu kada je riječ o modernističkom pokretu „mladih“ na prijelomu stoljeća? Je li on bio formalizirani i

\footnotetext{
Takav je pregled, prvenstveno s obzirom na historiografiju, za razdoblje do 1978. godine već uradila Ljerka Racko. Vidi: RACKO 1983. Nakon knjige Miroslava Šicela Književnost moderne iz 1978., kojom Racko završava svoj pregled, izašlo je nekoliko knjiga koje su se bavile ovom problematikom ili su je dijelom doticale, ali ne može se reći da se u glavnini trend proučavanja promijenio. Tako je, primjerice, Damir Agičić dodatno istražio djelatnost hrvatskih studenata u Pragu na kraju 19. stoljeća, uključujući i tzv. prašku grupu pokreta „mladih“. Tihana Luetić u svojoj se doktorskoj disertaciji o svakodnevici i društvenom životu studenata Sveučilišta u Zagrebu u drugoj polovici 19. i početku 20. stoljeća dotaknula i političke i kulturne djelatnosti zagrebačkih studenata, što nužno uključuje i problematiku modernističkog pokreta krajem 19. stoljeća. Također, hrvatski studenti koji su pohađali sveučilišta prvenstveno austrijskog dijela Monarhije, njihova organizacija i društvena djelatnost predmet su analize pojedinih poglavlja zbornika The Entangled Histories of Vienna, Zagreb and Budapest (18th - 20th Century). Na još neke naslove osvrćem se u nastavku teksta. Vidi: AGIČIĆ 2000; LUETIĆ 2012; IVELJIĆ 2015.
} 
strukturirani jedinstveni pokret ili neformalno heterogeno strujanje različitih ideja i grupacija? A drugo je pitanje, neovisno o odgovoru na prvo: je li modernistički pokret u bitnome smislu samo kulturno-umjetnički, odnosno prvenstveno književni fenomen, ili je riječ o sveobuhvatnom fenomenu koji inkorporira također područja politike i društva?

Kako modernistički pokret „mladih“ dosad nije bio predmet zasebne historiografske analize, povjesničari se nisu podrobno bavili tim problemom. Ipak, može se iščitati kako je implicitni pristup većine povjesničara koji su se tog fenomena dotaknuli u okviru svojih širih studija i sinteza takav da modernistički pokret „mladih“ razumijevaju prvenstveno kao sveobuhvatan društveni, politički i kulturni pokret. Rene Lovrenčić tako u knjizi Geneza politike ,novog kursa “ toj problematici posvećuje pozornost u okviru poglavlja naslovljenog „Mlada generacija buržoaske opozicije“. ${ }^{3}$ Međutim, iako ta knjiga predstavlja možda najbolju historiografsku razradu obrađivanog razdoblja i navedenog fenomena, njegov je pristup manjkav u dvojakom smislu, a to proizlazi iz činjenice da je njegov predmet istraživanja zapravo širi te da se na fenomen modernističkog pokreta oslanja u genetičko-teleološkom smislu. Tražeći u modernističkim gibanjima mlade generacije izvorište za koncepcije i prakse politike ,novog kursa“, nužno sužava svoj pogled na tzv. ,prašku grupu“ modernističkog pokreta te pritom gubi iz vida šira društvena i kulturna obilježja te ciljeve tog pokreta. Osim toga, kao što smo rekli, ne razmatra modernistički pokret kao samosvojni povijesni fenomen, nego je njegova perspektiva određena teleološki, što predstavlja osnovni metodološki problem njegova pristupa. Međutim, ono što je značajno jest da razumijeva pokret „mladih“ kao generacijski pokret, iako ga ne razmatra u komparativnoj perspektivi s drugim srodnim i istodobnim europskim modernističkim strujanjima. U jednom od najranijih publicističko-enciklopedijskih obrada ove problematike Mate Ujević će isto tako hrvatski modernistički pokret koncipirati kao omladinski, odnosno kao pokret „mladih“ koji nije imao čvrstu organizacijsku i ideološku strukturu, nego je predstavljao generacijska strujanja koja su stremila unijeti nove, modernističke ideje u hrvatski javni život, politiku i kulturu. ${ }^{4}$ Tome će jednako pristupiti i sâm sudionik pokreta Milan Marjanović koji u svojoj kasnoj antologiji kritike iz perioda hrvatske moderne pokret ne opisuje kao jedinstven i organiziran, nego kao vrenje novih ideja i ,prirodnu“" smjenu generacija. ${ }^{5}$

Definiciji modernističkog pokreta više su pozornosti posvetili književni povjesničari. U svojoj knjizi Časopisi hrvatskog modernističkog pokreta Vida Flaker predložila je pojmovno razlikovanje između hrvatske moderne kao pokreta, koji

\footnotetext{
LOVRENČIĆ 1972: 39-53.

4 UJEVIĆ 2015 [1933]: 7.

5 MARJANOVIĆ 1951: 5.
} 
onda još naziva i hrvatskim modernističkim pokretom, te hrvatske moderne kao stilskog razdoblja koje smješta između 1890. i 1914. godine. ${ }^{6}$ Takvu je distinkciju prihvatio i proveo Miroslav Šicel u knjizi Književnost moderne iz serije Povijest hrvatske književnosti, pomičući pritom vremenske granice razdoblja moderne na period između 1892. i 1916. godine, dok je pokret hrvatske moderne shvatio kao prvu fazu tog razdoblja moderne u trajanju između 1897. i 1903. godine. ${ }^{7}$ Krešimir Nemec i Marijan Bobinac također će ponuditi svoje kronološke odrednice, shvaćajući modernu kao „razdoblje novije hrvatske književnosti koje karakterizira ubrzano smjenjivanje stilskih pravaca i poetičkih opredjeljenja te njihova sinkronijska brojnost" u trajanju od 1895. do 1914. godine, zadržavajući također, makar implicitno, distinkciju spram hrvatskog modernističkog pokreta. ${ }^{8}$ Zanimljivo je, međutim, da iako oni modernu razumiju kao prvenstveno - ako ne i isključivo književni fenomen, njezine su kronološke granice eksplicitno omeđili društvenim i političkim događajima, naime, studentskom demonstracijom 1895. i izbijanjem Velikog rata 1914. godine. Očekivano, i obrnuto proporcionalno historiografskim pristupima, književni su povjesničari problem modernističkog pokreta primarno obrađivali kao književno-kulturni fenomen, iako su bili svjesni njegovih društvenih i političkih aspiracija. Slično tome, u okviru povijesti umjetnosti najistaknutija je preokupacija likovnom secesijom u Hrvatskoj. ${ }^{9}$ Pritom je naglasak stavljen na analizu samih umjetničkih djela te biografije umjetnika, dok je zapostavljena politička i društvena pozadina događanja. Mnogo je zastupljeniji pristup secesiji koji je promatra kao umjetničko-stilsko razdoblje nego kao društveni fenomen. I u slučaju književne povijesti i u slučaju povijesti umjetnosti, društveno-politički kontekst razmatrao se više kao ilustracija prilika u kojima nastaju pojedina umjetnička djela i nova umjetnička strujanja, a ne kao sredstvo u funkciji interpretacije cjeline djelatnosti modernističkog pokreta.

Vidljive su, dakle, tendencije prema razumijevanju modernističkog pokreta „mladih“ kao kulturnog, političkog i društvenoga generacijskog pokreta, koji, pak, treba razlikovati od razdoblja moderne u hrvatskoj kulturi i umjetnosti koje se proteže od 90 -ih godina 19. stoljeća pa sve do početka ili kraja Prvog svjetskog rata. Pojmovi ipak nisu posve jasno određeni. Možda je uzrok tome to što odnos pojma moderne spram drugih srodnih pojmova kao što su fin de siècle, secesija ili modernizam nije u potpunosti raščišćen. Ako govorimo o moderni kao o razdoblju, koji je njezin odnos i u čemu je njezina razlika spram koncepta fin de siècle? Ako, pak, govorimo o modernističkom pokretu isključivo u umjetničkom

\footnotetext{
FLAKER 1977: 9.
}

ŠICEL 1978: 8-12.

8 NEMEC I BOBINAC 1997: 84.

9 Vidi npr.: GAMULIN 1995; MARTINČIĆ I HACKENBERGER 1999; UKRAINČIK 1999; GALIĆ I GAŠPAROVIĆ 2003; KRAŠEVAC I VUGRINEC 2017. 
smislu, koja je njegova razlika spram secesije, osim što se potonja poglavito veže uz likovne umjetnosti, a prethodna uz književnost? Ne treba zaboraviti da je i hrvatski modernistički pokret predstavljao svojevrsnu secesiju od „starih“, da je prisvajao metode i vizualne identitete bečke secesije (Klub hrvatskih književnika, Hrvatski salon), kao i da je bio u tijesnoj suradnji s hrvatskim likovnim secesionistima (Mladost, Hrvatski salon, Život). Koji je, naposljetku, odnos pojma hrvatske moderne spram pojma modernizma, ako uzmemo u obzir da je ona predstavljala stilski vrlo heterogen fenomen koji je uključivao i neke elemente koje bi se u drugim europskim kontekstima smatralo upravo suprotstavljenima moderni (primjerice, naturalizam)? ${ }^{10}$

Koji god pristup da se odabere, važno je imati na umu dvije metodološke pretpostavke koje nam jedine mogu osigurati prikladan pristup tom fenomenu. Prvo, potrebno je istražiti u kojem su se smislu i na koji način pojmovima i konceptima koristili sami akteri s kojima imamo posla. Odnosno, drugim riječima, historija koncepata mora biti nužna pratiteljica intelektualne historije kako ne bismo zapali u anakronizam i kako bismo osvijestili povijesnu uvjetovanost pojmova kojima se koristimo te tako izbjegli rizik njihova nametanja prošlosti. I drugo, nužno je izbjeći redukciju - ponekad iz raznih profesionalnih razloga vrlo privlačnu - kompleksne i višeslojne prošle stvarnosti na određenu disciplinarnu matricu, bilo književnu, političku, socijalnu ili koju god drugu. Imajući to na umu, kao najplodniji pristup fenomenu hrvatskog modernističkog pokreta na prijelomu 19. i 20. stoljeća čini se onaj koji ga određuje kao široki, ali heterogeni i nestrukturirani kulturni, politički i društveni pokret, odnosno novo intelektualno i političko strujanje mladih, prije svega studenata i srednjoškolaca, od sredine 90 -ih godina 19. stoljeća do sredine prvog desetljeća 20. stoljeća. Ako prihvatimo takav pristup, za njegovo razumijevanje postaju ključni (ne)promijenjeni politički, kulturni i društveni konteksti fin de sièclea Hrvatske, odnosno Austro-Ugarske općenito, prije svega Beča i Praga kao središnjih formativnih mjesta za aktere pokreta. ${ }^{11}$ To naposljetku znači da se hrvatski modernistički pokret ne može reducirati na

10 Nikola Batušić, Zoran Kravar i Viktor Žmegač rade daljnju distinkciju između moderne, modernizma i moderniteta, pri čemu razlikuju „bečki pojam moderne“ koji se odnosi na književna kretanja oko godine 1900. te pojam moderne shvaćen u opreci moderna - postmoderna. Za pojam modernizma tvrde da se može koristiti i kao tipološka i kao periodizacijska kategorija, dok je pojam moderniteta isključivo tipološka kategorija. Doista, možemo se složiti s autorima da „tko danas govori o 'moderni', ne može pretpostavljati da će biti posve jasno što je njegov predmet.“ BATUŠIĆ, KRAVAR I ŽMEGAČ 2001: 7.

11 O kulturnim i intelektualnim kretanjima na prijelomu 19. i 20. stoljeća, kao i o njihovim urbanim sredinama, napisane su brojne izvrsne studije. Beč oko 1900. godine posebno je dobro istražena, ali i raspravljana tema. Ovdje navodim samo neke najreprezentativnije naslove: JOHNSTON 1993; SCHORSKE 1997; BARBARIĆ 1997; BELLER 2001; ŽMEGAČ 2012. Za pregled kulturnih i intelektualnih kretanja u Pragu na prijelomu 19. i 20. stoljeća vidi reprezentativnu monografiju WITTLICH 1992, kao i pojedine studije u zborniku radova PYNSENT 1989. 
kulturno-umjetničku dimenziju, ali se također ne može niti šablonizirati kao puka kopija općeeuropskog duha vremena ili intelektualne mode, nego se mora sagledati u svojem specifičnom kontekstu i s obzirom na svoje specifične ciljeve i uloge. Osim toga, imitacija i složenija aproprijacija koja uključuje i modifikaciju sadržaja mogu supostojati i ponekad čak proizvoditi kontradiktorne efekte, za što upravo modernistički pokret „mladih“ pruža izvrstan primjer. To još jače ističe važnost i interpretativnu funkciju konteksta za razumijevanje procesa formiranja intelektualnih struktura.

\section{Problem vremenskog i prostornog određenja}

Baš zato što u slučaju modernističkog pokreta „mladih“nije riječ o homogenom i čvrsto strukturiranom pokretu, nego o pojavi novih strujanja, prodoru novih pogleda i praksâ te, u krajnju ruku, o nastupu nove generacije, čiji su nositelji, ovisno o situaciji, djelovali i kao pokret i u okviru različitih grupacija, pa naposljetku i kao pojedinci, vrlo je teško govoriti o njegovim jasno utvrđenim vremenskim i prostornim odrednicama.

Ranije su već bili navedeni pokušaji vremenskog određenja koje su iznijeli različiti autori koji su se dotaknuli ovog fenomena. U tom se pogledu vrlo često kao ishodišna točka ističe godina 1895 . Pritom se kao značajna uzimaju dva događaja: studentsko spaljivanje mađarske „zastave“ prilikom posjeta Franje Josipa Zagrebu te tijesna pobjeda moderne drame Ive Vojnovića Ekvinocij na natječaju uprave zagrebačkog kazališta za najbolju dramu nad klasicističko-romantičarskom historijskom dramom Simeon Veliki Ante Tresića Pavičića. ${ }^{12}$ Pogotovo je prvi događaj u okviru političke historije kasnije okarakteriziran kao bitna prijelomnica, ,prolog velike drame hrvatske politike“. ${ }^{13}$ Nijedan od ovih dvaju događaja, međutim, ne odgovara u punom smislu onome što bi se trebalo smatrati početkom hrvatskog modernističkog pokreta. Spaljivanje mađarske zastave svakako je predstavljalo značajan javno-politički događaj, ali ujedno nije imao obilježja pravog, u punom smislu riječi formiranog političkog istupa nove generacije jer će se ta generacija - slijedom razvoja koji se odvio kao posljedica ovog događaja - tek obrazovati i intelektualno oblikovati na cislajtanijskim sveučilišnim središtima, prije svega u Pragu i Beču. Najvažiji dugoročni aspekt toga čina bila je implicitna

12 ŠICEL 1978: 305. Mađarska „Zastava“ stavljena je pod navodne znakove jer se nije zaista radilo o pravoj zastavi, a pogotovo ne o službenoj ugarskoj zastavi. Zapravo je to bila improvizirana mađarska trobojnica, vjerojatno sašivena za tu prigodu. Sami su studenti na suđenju tvrdili kako su namjerno pazili da to bude trobojnica, a ne zastava s grbovima. Intencija je, dakle, bila prirediti specifičan prosvjed protiv kršenja Nagodbe i mađarske dominacije u Hrvatskoj, a ne vrijeđati mađarske nacionalne simbole. Vidi: HRVATSKI DJACI 1895.

13 HORVAT 1990: 223. Koristan pregled historiografije o toj temi daje ŠIMETIN ŠEGVIĆ 2014: $1-13,152-165$. 
kritika inertnosti i impotentnosti političke opozicije Khuenu, međutim, izveden je upravo u onom političkom stilu koji će kasnije biti predmet kritike realistične naprednjačke omladine. Osim toga, studenti koji su izveli ovu demonstraciju bili su među sobom političko-ideološki heterogeni te su važnu ulogu igrali i pravaši koji će kasnije, najblaže rečeno, sa skepsom promatrati inicijative modernistički nastrojenih studenata, posebice onih napredne omladine. S druge strane, iako je Ivo Vojnović svakako bio jedan od najznačajnijih dramskih autora modernističkih tendencija, on nije pripadao pokretu „mladih“. Osim toga, moglo bi se pronaći i ranijih zrelih književnih ostvarenja s izraženom modernističkom tendencijom, primjerice, u opusu Janka Leskovara. Premda je, dakle, 1895. bila vrlo značajna godina u izražavanju novih političkih i kulturnih tendencija, ne može se uzeti kao točka geneze novih strujanja. ${ }^{14}$

Jednako tako, kao gornja vremenska odrednica često se ističe 1914. godina. Međutim, iako su nove politike koje su dijelom inaugurirali „mladi“" svakako bile faktor u genezi Velikog rata, sama hrvatska moderna najkasnije do 1904./1905. godine kao pokret više ne postoji. Borbe „mladih“ i „starih“ jenjavaju, „mladi“ ulaze u institucije ,starih“ i postaju dio društvene, političke i kulturne elite (iako su to već dobrim dijelom bili i ranije). S druge, pak, strane, kulturni i simbolički kapital pokreta u više se navrata ponovno mobilizirao i koristio u kasnijim javnim polemikama i političkim obračunima, no svaki put u izmijenjenim kontekstima i s drugačijim polazišnim pozicijama aktera.

Općenito bi bilo potrebno dovesti u pitanje punktualističko razumijevanje vremenskog određivanja intelektualnih formacija. Korijeni hrvatskog modernističkog pokreta višestruki su. Oni se moraju tražiti u domaćim intelektualnim, kulturnim i političkim tradicijama i okolnostima, kao što su ilirizam, jugoslavenstvo, pravaštvo (posebice omladinsko), šenoinska koncepcija književnosti, đačka društva i listovi itd., ali i u formativnim iskustvima u imperijalnim centrima te u aproprijaciji širih europskih kretanja. Jednako je i s određivanjem „trenutka“ istupa „mladih“. „Mladi“" nisu istupili samo jednom, već su to činili mnogo puta, svaki put pokušavajući se probiti do sve šire publike. Učinili su to 1895. spaljivanjem zastave, u istupima na suđenju koje je uslijedilo, nadalje prilikom objave svakog od svojih brojnih novih časopisa te u nebrojenim tekstovima i javnim polemikama. Sve to upućuje na nužnost višeslojnog vremenskog razumijevanja geneze i razvoja hrvatskog modernističkog pokreta koje razmatranje ne ograničava čvrstim i fiksiranim vremenskim okvirima.

S prostornim je određenjem situacija mnogo jasnija. Posve je izvjesno da se u prostornom smislu nije moguće ograničavati državnopravnim okvirima, već je

14 To ne znači da se demonstrativan istup omladine 1895. godine, iako ideološki neizgrađen, može zanemariti. On je predstavljao fokalnu simboličku točku koja je ne samo presudno utjecala na njihove sudbine nego je ujedno bila svojevrstan trajni simbolički kapital „mladih“. 
potrebno pratiti stvarna kretanja stvarnih ljudi. Najvažniji prostori za proučavanje modernističkog pokreta „mladih“ svakako su Zagreb, Beč i Prag. Međutim, ono što je važno naglasiti je da to nisu tri odvojene prostorne točke ili monade, nego prostori u interakciji, dijelovi većeg imperijalnog prostora, čije su međusobne „silnice“ bitno utjecale na definiranje kulturnih, političkih i društvenih uvjeta i obzorja. Osim toga, značajna su i šira europska kretanja. Zbog toga se ne može govoriti o „hrvatskoj povijesti“ u ovom ili onom kontekstu, nego o povijesti intelektualnih, društvenih i političkih strujanja na habsburškom imperijalnom prostoru sagledanih iz perspektive određenih aktera u tom prostoru.

\section{Problem unutrašnje podjele}

Kada se govori o hrvatskom modernističkom pokretu kao o heterogenom pokretu „mladih“, obično se unutar njega identificiraju određene grupe kojima se potom pripisuju različita obilježja, ideološki naglasci te područja djelovanja. Najčešća podjela jest ona na tzv. bečku grupu i na tzv. prašku ili praško-zagrebačku grupu. ${ }^{15}$ Pritom se prvu opisuje kao artističku, esteticističku i kozmopolitsku, a drugu kao socijalno-političku, nacionalističku i realističku. Područje djelovanja prve ograničava se isključivo na književnost, književnu kritiku i eventualno likovnu umjetnost, a druge na politiku i socijalna pitanja. Prva je pod snažnim utjecajem bečke moderne, prije svega Hermanna Bahra, a druga pod utjecajem Tomáša Garriguea Masaryka i čeških naprednjaka. Neki autori razlikuju više grupa. Mate Ujević tako dijeli pokret na „realiste“ (praški krug oko Hrvatske misli te kasnije Novog doba i Glasa), ,naprednjake“ (karlovačko-zagrebački krug oko Nade, Nove nade i drugih manjih časopisa), „moderniste“ (bečki krug oko Mladosti, Hrvatskog salona i Života) te ,nacionaliste“ (krug oko Narodne misli). ${ }^{16}$ Ujević realistima obilježava onu grupaciju (,prašku skupinu“) koja je bila pod najsnažnijim utjecajem Tomáša G. Masaryka, a čiji je spiritus movens u ovom razdoblju bio Stjepan Radić. Oni su u prvi plan stavljali socijalna i ekonomska pitanja, zalagali se za kršćanski moralizam, odbacivali larpurlartizam te zagovarali individualizam u službi izgradnje čvrstog narodnog karaktera. ${ }^{17}$ Naprednjaci su, prema Ujeviću, predstavljali mlađu generaciju okupljenu oko listova Nada, Nova nada i drugih manjih listova. Oni su bili pod snažnim utjecajem praške grupe realista, ali su također modificirali njihove ideje te unijeli i neke svoje. Njihov je naglasak tako bio na obrazovanju pojedinca, organizacijskim pitanjima pokreta te individualizmu. Zalagali su se za utilitarni pristup književnosti, ali su ujedno

\footnotetext{
15 Tako npr. NEMEC i BOBINAC 1997: 84, a i M. Šicel te V. Flaker barataju distinkcijom „bečani“ - „pražani“, iako manje eksplicitno.

16 UJEVIĆ 2015 [1933]: 69-70.

17 Isto: 88.
} 
bili pristaše moderne i kriticizma. ${ }^{18}$ Iako su isprva bili pod snažnim utjecajem praških realista, kasnije su razvili distinktivne političke i kulturne poglede koji su u mnogočemu bili u opreci s onima realista, ali i bečkih modernista. Upravo su potonji, prema Ujeviću, najuže vezani uz europska kulturna strujanja koja se označavaju pokretom moderne. Predvođeni Milivojem Dežmanom, zalagali su se za subjektivizam i individualizam, otvorenost prema europskim strujanjima, slobodu misli i izražavanja te originalnost. ${ }^{19}$ Naposljetku, Ujević nacionalistima označava krug oko zagrebačke Narodne misli koji je naglašavao objektivno narodno jedinstvo Srba i Hrvata te pomanjkanje subjektivne svijesti o tom jedinstvu. Oni su se prema „starima“ od svih navedenih skupina odnosili najblaže i politički agitativno. ${ }^{20}$ Takav se Ujevićev pristup, koji odstupa od uobičajene binarne dihotomije, čini plodnim, pogotovo ako se uspiju pokazati brojne sličnosti između tih grupacija, njihova dijeljena ideološka, kulturna i politička stajališta te česte interakcije i (pokušaji) zajedničkih pothvata.

Modernistički pokret „mladih“ kako je ovdje definiran doista je bio heterogen $\mathrm{i}$ nestrukturiran pokret koji je funkcionirao na temelju grupacija koje su se najčešće okupljale oko pothvata izdavanja nekog časopisa. Međutim, treba biti oprezan da se te grupacije ne shvate odviše kruto te da im se ne podari monadološki karakter. Takav pristup potencijalno vodi u smjeru toga da se sa svakom od tih grupa poveže određena vrsta historijskog istraživanja, npr. političko-historijskog s ,praškom grupom“ ili književno-historijskog s „,bečkom grupom“ te da se tako iz vida izgubi cjelina pokreta, kao i unutrašnja dinamika te interakcija njegovih aktera. Umjesto takve provincijalizacije pristupa, potrebno je pratiti grupnu dinamiku i dinamiku široke mreže pokreta, zadržavajući pritom svijest o njegovoj heterogenosti i fluidnosti. ${ }^{21} \mathrm{U}$ tom pogledu od najveće koristi mogle bi biti sačuvane korespondencije aktera, koje su u velikoj mjeri kao povijesni izvor neiskorištene.

\section{Problem izvora}

Od najranijih prikaza modernističkog pokreta „mladih“, temelj za rekonstrukciju ideologije i intelektualnih strujanja pokreta bili su njegovi časopisi. ${ }^{22}$ To se odnosi jednako na historiografiju i na književnu historiju. Časopisi su doista bili

\footnotetext{
18 Isto: $110-111$.

19 Isto: 120.

20 Isto: 140.

21 Dobar je primjer takvog pristupa, iako posve sintetičan i općenit, onaj u poglavlju „Napredna omladina i njene ideje“ u knjizi ŠIDAK, GROSS, KARAMAN I ŠEPIĆ 1968: 152-155, kao i u LOVRENČIĆ 1972: 39-54 (poglavlje „Mlada generacija buržoaske opozicije“).

22 Tako npr. UJEVIĆ [1933] 2015; MARJANOVIĆ 1951; FLAKER 1977; MARIJANOVIĆ 1990.
} 
centralni za pokret „mladih“. Oni su predstavljali njegov glavni medij te mjesto formiranja stajališta, za što su posebice bili značajni tekstovi manifestnog karaktera. Za hrvatsku modernu općenito je karakteristična važnost književne kritike, čak i u većoj mjeri nego sama književna produkcija. ${ }^{23}$ Proglasima, polemičkim tekstovima, esejima, studijama autora te književnim kritikama mladi su predstavnici moderne izgrađivali nove nazore o književnosti, politici i društvu općenito, unoseći u hrvatsku javnost šira europska strujanja koja su pritom modificirali prema lokalnim uvjetima i potrebama. Oni stoga predstavljaju temeljni izvor za intelektualnu rekonstrukciju hrvatskog modernističkog pokreta.

Međutim, tek se u suglasju s drugim izvorima može steći relevantna slika o cjelini intelektualnih razvojnih puteva, ideoloških konstrukcija, političkih angažmana, osobnih veza i uloga aktera hrvatskog modernističkog pokreta. U tom pogledu komplementarnu ulogu u centralnim tekstovima igra građa osobnih ostavština samih povijesnih aktera, prije svega njihova korespondencija. ${ }^{24}$ Osim toga, značajni su i zapisnici te drugi dokumenti formalnih i neformalnih tijela i društava koja su služila kao organizacijska osnovica za djelatnost modernističkog pokreta, što obuhvaća razna uredništva časopisa, đačka i studentska društva itd. Za evaluaciju značenja i važnosti pokreta bitnu ulogu imaju i memoaristika te kasnija publicistika samih aktera pokreta.

Naravno da se ne smije zapostaviti niti sama književna produkcija. Ona ima dvojaku interpretativnu funkciju. Analizom književnih djela moderne može se pokazati kako su predstavnici moderne zamišljali ulogu književnosti, koje su bile njihove estetske norme i na koje su se uzore oslanjali te kako su se odnosili spram domaće književne tradicije. S druge strane, ona također može ukazivati na korištenje književnošću kao sredstvom za propagiranje određenih političkih stavova, napose onih koji se odnose na kritiku postojećih društvenih odnosa. U tom je smislu prije svega kontekstualnim čitanjem književnih djela moguće rekonstruirati njegove političke ili šire društvene uloge, čak i u slučaju onih, napose esteticističkih, djela čija je intencionalna funkcija deklaratorno larpurlartistička.

\section{Problem utjecaja}

Nova intelektualna historija, koja pod utjecajem sociološke historije nastaje kao reakcija na idealizam tradicionalne historije ideja, kako ju je koncipirao Arthur O. Lovejoy, sumnjičava je spram koncepta „utjecaja“ jer se on u idealističkoj historiji ideja svodio na transtemporalne genealogije ideja neovisno o njihovom društvenom i političkom kontekstu. ${ }^{25} \mathrm{Na}$ kontekstualizaciji ideja posebno je inzi-

23 MARJANOVIĆ 1951: 7.

24 Određeni izvori već su objavljeni. Vidi: KRIZMAN 1972; AGIČIĆ 2003; IVELJIĆ 2008.

25 MCMAHON I MOYN 2014: 5. 
stirala tzv. kembrička škola koju u teorijskom smislu predvodi Quentin Skinner. Međutim, njihovi su kritičari ukazivali na to da je kontekst u okviru kembričke škole shvaćen kao diskurzivni kontekst, kontekst drugih ideja i diskursa, dok je materijalni, društveni i politički kontekst ostao zanemaren. ${ }^{26}$ Tako se samo u novom ruhu perpetuira središnji epistemološki problem intelektualne historije, naime, onaj dualizma između materijalizma i idealizma, između ideja i misli te materijalne stvarnosti.

Istraživačka problematika modernističkog pokreta „mladih“ na prijelomu 19. i 20. stoljeća zbog svoje naravi predstavlja izvrstan predmet za pristup koji bi se mogao opisati kao socijalno i politički kontekstualizirana intelektualna historija. Prije svega, njegovo široko prostorno određenje uvjetuje dinamičnost konteksta, posebice u smislu odnosa centara i periferija te ujedno višeznačnosti habsburškog transnacionalnog imperijalnog prostora, kao i u odnosu posredovanja spram šireg europskog fin de siècle političkog, društvenog i intelektualnog konteksta. Ideje i ideologija pokreta „mladih“ razvijale su se u dinamičnom međuodnosu sličnosti i razlika konteksta Banske Hrvatske, Austrije i Češke, odnosno Zagreba, Beča i Praga kao kulturnih i intelektualnih središta. Na njih su jednako utjecale široke društvene promjene te diskrepancije i antagonizmi koji su s njima dolazili, kao i različita kulturna strujanja. Sve to uvjetuje nužnost pristupa koji se ne bi ograničavao na idejne utjecaje, pa niti isključivo na intelektualne kontekste, nego koji bi proučavao transfere, aproprijacije i recepcije ideja, ideoloških sustava i diskursa u promijenjenim i promjenjivim društvenim, političkim i kulturnim kontekstima.

Takav bi pristup mogao pomoći dati odgovor na često postavljano pitanje o izvornosti, odnosno autohtonosti hrvatskog modernističkog pokreta. Drugim riječima, razmatralo se je li moderna zapravo „uvezena“ u Hrvatsku, gdje ona navodno nije imala svoje kulturno i društveno utemeljenje. U svjetlu ranije opisanog pristupa takvo je pitanje izlišno. Ni moderna ni hrvatski društveno-kulturni kontekst nisu fiksirani entiteti, nego su pojmovne oznake za složene i dinamične fenomene koji su ujedno višeznačni i promjenjivi. Transferi, aproprijacije i recepcije u promijenjenim i promjenjivim političkim, društvenim i kulturnim kontekstima uvjetuju adaptacije ideja, misaonih konstrukcija i kulturno-umjetničkih strujanja. U tom smislu model koji inzistira na uspoređivanju navodno centrifugalnih fenomena s centralno pozicioniranim idealtipom nužno vodi u izrazitu redukciju prošle stvarnosti te ispušta iz vida specifičnosti istraživanih fenomena koje ne proizlaze iz njegovih „,devijantnih“ ili „posebnih“ svojstava, nego iz mutacija sadržaja koje su uvjetovane promijenjenim društvenim kontekstima. Uostalom, ni u svojim izvorištima intelektualni fenomeni ne opstoje u čistim i idealiziranim oblicima, nego su uvijek sačinjeni od kompleksnih i heterogenih elemenata koji mogu biti i u međusobnoj napetosti i kontradikciji. Modernistički pokret „mladih“ stoga je

$26 \quad$ Vidi npr. MEIKSINS WOOD 2016: 49-53. 
nužno promatrati ne samo kao iteraciju općih europskih modernističkih kretanja koja zbog svoje marginalne, ,zaostale“ sredine odstupa od nekog idealtipski postavljenog modernističkog pokreta (najčešće onog bečkog), nego kao samosvojni fenomen koji je određena intelektualna kretanja aproprirao i prilagodio - svjesno ili nesvjesno - svojim konkretnim prilikama, potrebama i ciljevima.

\section{Problem teleologije}

Modernistički pokret „mladih“ često je kao predmet istraživanja bio obuhvaćen tek u okviru nekog šireg istraživačkog projekta, pri čemu je on predstavljao kariku, manje ili više bitan element za određen daljnji razvoj koji čini osnovnu svrhu istraživanja. To je slučaj, primjerice, pri razmatranju geneze politike „,novog kursa" ili u pogledu istraživanja različitih književnih utjecaja i preteča dvadesetostoljetnog modernizma. Ovdje se javlja problem teleologije. Dakako da je posve legitimno istraživati genealogiju određenog fenomena, i to tako da se u sklopu nje obuhvati i neki drugi značajan fenomen. Međutim, ako je istraživački interes primarno usmjeren spram hrvatskog modernističkog pokreta, onda ga je nužno sagledati u njegovu vlastitom svjetlu, u njegovim vlastitim okvirima i horizontima, dakako, u širem kontekstu intelektualnih, kulturnih, društvenih i političkih kretanja. Svakako nije moguće ignorirati postojanje kasnijeg razvoja, kao i njegovo poznavanje, ali u metodološkom smislu potreban je oprez da se pitanja koja se postavljaju ne formuliraju iz perspektive onog što dolazi poslije (dakle, anakrono) i da se slijedom toga nužan proces selekcioniranja izvora i interpretacije ne svede na utvrđivanje ranije spomenutih spornih ,utjecaja“.

$\mathrm{S}$ time je povezana i rasprava o kraju modernističkog pokreta. S obzirom na distinkciju iznesenu na početku između pokreta hrvatske moderne i moderne kao (stilskog) razdoblja, može se ustvrditi kako završetak hrvatskog modernističkog pokreta, koji se može smjestiti u sredinu 1900-ih, ne znači nužno i kraj moderne. Rezultat hrvatskog modernističkog pokreta bile su bitne transformacije u književnosti, kulturi i politici Hrvatske. One se prije svega odnose na promjenu oblika i metoda javnog djelovanja. Zauzimanjem važnih pozicija u političkim i kulturnim strukturama Banske Hrvatske od strane „mladih“, te su nove prakse i pogledi kontinuirano živjeli i bili djelatni u dužem vremenskom periodu te su također bitno usmjeravali daljnji tijek povijesnog razvoja Hrvatske, ali i šireg imperijalnog prostora, kako u kulturnom tako i u društveno-političkom pogledu. Osim toga, i nakon njegova stvarnog završetka, hrvatski modernistički pokret i kasnije evocirali su njegovi i drugi akteri kao važan simbolički kapital. Sve je to potrebno imati na umu kada se ocjenjuju rezultati i važnost fenomena modernističkog pokreta „mladih“. 


\section{Zaključak}

Zbog same naravi modernističkog pokreta „mladih“, koji je u svojoj intenciji i obuhvatu bio i kulturni, i politički, i društveni, za njegovo potpuno razumijevanje potreban je interdisciplinarni pristup. Intelektualna historija, shvaćena ne kao historija ideja, nego kao historija koncepata i mišljenja konkretnih povijesnih aktera u određenim društvenim, političkim i kulturnim kontekstima, predstavlja prikladan metodološki okvir za ovu problematiku. Potrebno je preispitati kategorijalni aparat i koncepte koji se uobičajeno koriste za razmatranje fenomena hrvatskog modernističkog pokreta.

Fenomen modernističkog pokreta „mladih“ historiografski je relevantan iz barem dva razloga. Prije svega, povijesna je važnost samog pokreta u konstituiranju novog poimanja - u najmanju ruku novog smjera - kulture i politike iznimno velika, a njegova je dubinska istraženost s obzirom na to disproporcionalno mala. Kao generacijski pokret, kroz njega su stasali ljudi koji su preuzeli ključne pozicije u hrvatskoj kulturi i politici te postali dio elita koje su u velikoj mjeri krojile smjer razvoja hrvatskog društva prije, tijekom i u godinama nakon Prvog svjetskog rata. Osim toga, taj fenomen omogućava upotrebu pristupâ koji predstavljaju značajan doprinos razvoju domaće historiografije. Riječ je o transnacionalnim pristupima kada se radi o širem europskom kontekstu moderne, o razmjenama ideja i koncepata te o konkretnim kretanjima i mrežama samih aktera; o interdisciplinarnom pristupu analizi višeslojnog i sveobuhvatnog fenomena kao što je hrvatska moderna, posebice prilikom čitanja književnog teksta; te o kontekstualnom utemeljenju intelektualne historije koja razmatranje ideja, koncepata, argumentacija i mišljenja smješta u konkretan politički, društveni i kulturni okvir, kako s obzirom na šire strukture tako i s obzirom na određene povijesne aktere. U tom je smislu ova tematika dvostruko poticajna: kao uvelike zanemareno i u dubinskom smislu neistraženo područje od velikog povijesnog značenja te kao problematika prikladna za primjenu relevantnih i aktualnih istraživačkih teorija i metoda. 


\section{Bibliografija}

AGIČIĆ, Damir. 2000. Hrvatsko-češki odnosi na prijelazu iz XIX. u XX. stoljeće. Zagreb: Ibis grafika.

AGIČIĆ, Damir. 2003. Dragi Franta! Hrvatska korespondencija Františeka Hlaváčeka (1896.-1904.). Zagreb: Srednja Europa.

BARBARIĆ, Damir (ur.). 1997. Fin de siècle Zagreb-Beč. Zagreb: Školska knjiga.

BATUŠIĆ, Nikola, Zoran KRAVAR, Viktor ŽMEGAČ. 2001. Književni protusvjetovi. Poglavlja iz hrvatske moderne. Zagreb: Matica hrvatska.

BELLER, Steven (ur.). 2001. Rethinking Vienna 1900. New York - Oxford: Berghahn Books.

FLAKER, Vida. 1977. Časopisi hrvatskoga modernističkog pokreta. Zagreb: Hrvatsko filološko društvo.

GALIĆ, Anđelka, Miroslav GAŠPAROVIĆ (ur.). 2003. Secesija u Hrvatskoj. Zagreb: Muzej za umjetnost i obrt.

GAMULIN, Grgo. 1995. Hrvatsko slikarstvo XIX. stoljeća, sv. 2: Hrvatsko slikarstvo na prijelazu iz XIX. u XX. stoljeće. Zagreb: Naklada Naprijed.

HORVAT, Josip. 1990. Politička povijest Hrvatske, dio 1. Zagreb: August Cesarec.

Hrvatski djaci pred sudom: stenografski izvještaj o glavnoj razpravi proti hrvatskim sveučilištnim djacima obdržanoj pred kr. sudbenim stolom u Zagrebu dne 11-16. studenoga 1895. Zagreb: Dionička tiskara.

IVELJIĆ, Iskra. 2008. Od uza Sudbenog stola do turneje po Rusiji. Nepoznata pisma Josipa Henneberga iz 1894.-1897. Časopis za suvremenu povijest 40: 587-623.

IVELJIĆ, Iskra (ur.). 2015. The Entangled Histories of Vienna, Zagreb and Budapest (18th - 20th Century). Zagreb: FF Press.

JOHNSTON, William M. 1993. Austrijski duh: intelektualna i društvena povijest od 1848. do 1938. Zagreb: Nakladni zavod Globus.

KRAŠEVAC, Irena, Petra VUGRINEC (ur.). 2017. Izazov moderne: Zagreb i Beč oko 1900. Slikarstvo, kiparstvo i arhitektura zagrebačke i bečke secesije. Zagreb: Galerija Klovićevi dvori.

KRIZMAN, Bogdan. 1972. Korespondencija Stjepana Radića, 1885.-1918. Zagreb: Sveučilište u Zagrebu.

LOVRENČIĆ, Rene. 1972. Geneza politike „novog kursa“. Zagreb: Sveučilište u Zagrebu.

LUETIĆ, Tihana. 2012. Studenti Sveučilišta u Zagrebu (1874-1914). Društveni život, svakodnevica, kultura, politika. Zagreb: Srednja Europa.

MARIJANOVIĆ, Stanislav. 1990. Fin de siècle hrvatske moderne (generacije „, mladih “ i časopis ,Mladost“). Osijek: Revija.

MARJANOVIĆ, Milan. 1951. Hrvatska moderna. Izbor književne kritike, knj. I.-II. Zagreb: Jugoslavenska akademija znanosti i umjetnosti. 
MARTINČIĆ, Julijo, Dubravka HACKENBERGER (ur.). 1999. Secesija u Hrvatskoj: zbornik radova znanstvenog skupa. Zagreb - Osijek: Hrvatska akademija znanosti i umjetnosti.

MCMAHON, Darrin M., Samuel MOYN (ur.). 2014. Rethinking Modern European Intellectual History. Oxford - New York: Oxford University Press.

MEIKSINS WOOD, Ellen. 2016. Društvena i politička misao: socijalna historija političke teorije. С̆етu 13: 49-95.

NEMEC, Krešimir, Marijan BOBINAC. 1997. Bečka i hrvatska moderna: poticaji i paralele. U BARBARIĆ 2007: 84-105.

PYNSENT, Robert (ur.). 1989. Decadence and Innovation: Austro-Hungarian Life and Art at the Turn of the Century. London: Weidenfeld \& Nicolson.

RACKO, Ljerka. 1983. Pokret hrvatske moderne u historiografiji. Historijski zbornik 36: $1-31$.

SCHORSKE, Carl E. 1997. Beč krajem stoljeća: Politika i kultura. Zagreb: Izdanja Antibarbarus.

ŠICEL, Miroslav. 1978. Književnost moderne [Povijest hrvatske književnosti, knj. 5]. Zagreb: Liber.

ŠIDAK, Jaroslav, Mirjana GROSS, Igor KARAMAN, Dragovan ŠEPIĆ. 1968. Povijest hrvatskog naroda g. 1860-1914. Zagreb: Školska knjiga.

ŠIMETIN ŠEGVIĆ, Filip. 2014. Patriotizam i bunt: Franjo Josip I. u Zagrebu 1895. godine. Zagreb: Srednja Europa.

UJEVIĆ, Mate. 2015 [1933]. Prilozi za povijest pokreta hrvatske omladine koncem XIX i početkom XX stoljeća, s osobitim osvrtom na borbu starih i mladih. Zagreb: Alfa.

UKRAINČIK, Lea (ur.). 1999. Hrvatski salon, Zagreb 1898.: 100 godina Umjetničkog paviljona. Zagreb: Umjetnički paviljon u Zagrebu.

WITTLICH, Petr. 1992. Prague: fin de siècle: 1890-1914. Paris: Flammarion.

ŽMEGAČ, Viktor. 2012. Bečka moderna: portret jedne kulture, 2. prošireno izd. Zagreb: Matica hrvatska. 


\section{Towards an intellectual history of the Croatian Modernist movement at the turn of the $20^{\text {th }}$ century: state of research and research problems}

The Croatian Modernist movement (also called the Youth Movement) has not been the subject of extensive historiographic research. There is no monograph dealing exclusively with this topic. It was mostly included in broader research and featured in overviews of political history, which narrowed the focus to political and social aspects of the movement. On the other hand, literary and art history for the most part focused on literary, artistic, or more broadly cultural aspects of the movement. This was reflected in the terminological discrepancies, as well as a clear disciplinary segregation which obscured the historical significance of the movement as a phenomenon sui generis.

In this paper, several theoretical and methodological problems which arise in dealing with the problem of the fin de siècle Croatian Modernist movement are explored. They are viewed from the standpoint of intellectual history as a rendezvous discipline in an attempt to integrate diverse disciplinary perspectives and approaches. The first problem is concerned with the definition of the research object itself, i.e. the question whether the Youth Movement was a formal and homogeneous movement, or an informal and heterogeneous intellectual and cultural current. Closely related to this is the second problem of the chronological and spatial dimensions of the movement, which brings forth the transnational aspect of the phenomenon and also the necessary comparisons with other fin de siècle European Modernist movements. Thirdly, the question of the movement's internal division is explored, touching mostly on the aforementioned disciplinary segregation of research on the topic. Following that is a brief discussion of the various sources that are at our disposal for the investigation of the Croatian Modernist movement. Finally, two more closely theoretical and methodological questions are elaborated: the concept of 'influence' and its critique within contemporary debates in intellectual history, and the methodological problem of teleology when dealing with fin de siècle phenomena in their relationship to $20^{\text {th }}$ century developments.

Key words: fin de siècle, Modernist movement, Croatian history, historiography, literary history, art history, intellectual history.

Ključne riječi: fin de siècle, modernistički pokret, hrvatska povijest, historiografija, književna povijest, povijest umjetnosti, intelektualna historija.

Nikola Tomašegović Filozofski fakultet Sveučilišta u Zagrebu Ivana Lučića 3 HR-10000 Zagreb ntomaseg@ffzg.hr 


\section{FILOZOFSKI FAKULTET SVEUČILIŠTA U ZAGREBU \\ ZAVOD ZA HRVATSKU POVIJEST \\ INSTITUTE OF CROATIAN HISTORY \\ INSTITUT FÜR KROATISCHE GESCHICHTE}

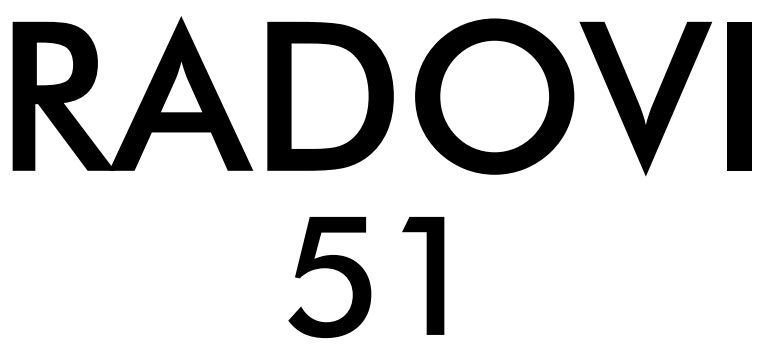

BROJ 2

ZAVOD ZA HRVATSKU POVIJEST

FILOZOFSKOGA FAKULTETA SVEUČILIŠTA U ZAGREBU

\section{FF press}

ZAGREB 2019. 


\title{
RADOVI ZAVODA ZA HRVATSKU POVIJEST FILOZOFSKOGA FAKULTETA SVEUČILIŠTA U ZAGREBU
}

\author{
Knjiga 51, broj 2
}

\author{
Izdavač / Publisher \\ Zavod za hrvatsku povijest \\ Filozofskoga fakulteta Sveučilišta u Zagrebu \\ FF-press \\ Za izdavača / For Publisher \\ Vesna Vlahović Štetić \\ Glavni urednik / Editor-in-Chief \\ Inga Vilogorac Brčić \\ Izvršni urednik / Executive Editor \\ Kornelija Jurin Starčević \\ Uredništvo / Editorial Board
}

Jasmina Osterman (stara povijest/ancient history), Trpimir Vedriš (srednji vijek/medieval history), Hrvoje Petrić (rani novi vijek/early modern history), Željko Holjevac (moderna povijest/ modern history), Tvrtko Jakovina (suvremena povijest/contemporary history), Silvija Pisk

(mikrohistorija i zavičajna povijest/microhistory and local history),

Zrinka Blažević (teorija i metodologija povijesti/theory and methodology of history)

Međunarodno uredničko vijeće / International Editorial Council

Denis Alimov (Sankt Peterburg), Živko Andrijašević (Nikšić), Csaba Békés (Budapest), Rajko

Bratož (Ljubljana), Svetlozar Eldarov (Sofija), Toni Filiposki (Skopje), Aleksandar Fotić

(Beograd), Vladan Gavrilović (Novi Sad), Alojz Ivanišević (Wien),

Egidio Ivetić (Padova), Husnija Kamberović (Sarajevo), Karl Kaser (Graz),

Irina Ognyanova (Sofija), Géza Pálffy (Budapest), Ioan-Aurel Pop (Cluj),

Nade Proeva (Skopje), Alexios Savvides (Kalamata), Vlada Stanković (Beograd),

Ludwig Steindorff (Kiel), Peter Štih (Ljubljana)

Izvršni urednik za tuzemnu i inozemnu razmjenu /

Executive Editor for Publications Exchange

Martin Previšić

Tajnik uredništva / Editorial Board Assistant

Dejan Zadro

Adresa uredništva/Editorial Board address

Zavod za hrvatsku povijest, Filozofski fakultet Zagreb, Ivana Lučića 3, HR-10 000, Zagreb Tel. ++385(0)1 6120191

Časopis izlazi jedanput godišnje / The Journal is published once a year

Časopis je u digitalnom obliku dostupan na / The Journal in digital form is accessible at Portal znanstvenih časopisa Republike Hrvatske „Hrčak“ http://hrcak.srce.hr/radovi-zhp

Financijska potpora za tisak časopisa / The Journal is published with the support by Ministarstvo znanosti, obrazovanja i športa Republike Hrvatske

Časopis je indeksiran u sljedećim bazama / The Journal is indexed in the following databases: Directory of Open Access Journals, EBSCO, SCOPUS, ERIH PLUS, Emerging Sources Citation Index - Web of Science 


\title{
Naslovna stranica / Title page by Marko Maraković
}

\section{Grafičko oblikovanje i računalni slog / Graphic design and layout Marko Maraković}

\author{
Lektura / Language editors \\ Samanta Paronić (hrvatski / Croatian) \\ Edward Bosnar (engleski / English)
}

Tisak / Printed by

Tiskara Zelina, Sv. Ivan Zelina

Naklada / Issued

200 primjeraka / 200 copies

Ilustracija na naslovnici

Muza Klio (Alexander S. Murray, Manual of Mythology, London 1898)

Časopis je u digitalnom obliku dostupan na Portalu znanstvenih časopisa Republike Hrvatske ,Hrčak“ http://hrcak.srce.hr/radovi-zhp

The Journal is accessible in digital form at the Hrcak - Portal of scientific journals of Croatia http://hrcak.srce.hr/radovi-zhp 